\title{
Effect of Glutaraldehyde Concentration on Catalytic Efficacy of Candida rugosa Lipase Immobilized onto Silica from Oil Palm Leaves
}

\author{
Emmanuel Onoja ${ }^{1, *}$ and Roswanira Abdul Wahab ${ }^{2, * *}$ \\ ${ }^{1}$ Department of Science Laboratory Technology, The Federal Polytechnic, Kaura Namoda, P.M.B. 1012, Zamfara State, Nigeria \\ ${ }^{2}$ Department of Chemistry, Faculty of Science, Universiti Teknologi Malaysia, 81310, UTM Johor Bahru, Johor, Malaysia
}

*Corresponding author:

tel: $+234-7037708575^{*}$;

$+60-126292146^{* *}$

email: onojaemmanuel30@yahoo.com*;

roswanira@kimia.fs.utm.my ** $^{* *}$

Received: December 26, 2018

Accepted: March 18, 2019

DOI: $10.22146 / \mathrm{ijc} .42177$

\begin{abstract}
Till date, studies that investigated the effect of glutaraldehyde concentration on catalytic efficacy of biocatalyst developed with silica-derived from oil palm leaves $(O P L)$ as support, are unknown. The study presents the preparation of support consisting of silica extracted from OPL coated over magnetite $\left(\mathrm{G} / \mathrm{A} / \mathrm{SiO}_{2}-\mathrm{M}\right)$ for the immobilization of Candida rugosa lipase (CRL). Herein, the effect of glutaraldehyde concentration on the catalytic efficacy of immobilized CRL was assessed by the enzymatic production of butyl butyrate as a model. Fourier transform infrared (FTIR) spectra and immobilization parameters indicated that covalent bound CRL on functionalized OPL-derived silicamagnetite composite activated with $4 \%(v / v)$ glutaraldehyde solution (100 mM, pH 7.0) $\left(\mathrm{CRL} / \mathrm{G} / \mathrm{A} / \mathrm{SiO}_{2}-\mathrm{M}\right)$ and pretreated in toluene, resulted in a protein loading and an immobilization yield of $68.3 \mathrm{mg} / \mathrm{g}$ and $74.3 \%$, respectively. The resultant $\mathrm{CRL} / \mathrm{G} / \mathrm{A} / \mathrm{SiO}_{2^{-}}$ $M$ biocatalyst with a specific activity of $61.9 \mathrm{U} / \mathrm{g}$ could catalyze the esterification production of $76.5 \%$ butyl butyrate in just $3 \mathrm{~h}$, as confirmed by analyses of the purified ester using FTIR and ${ }^{1} H$ NMR spectroscopy. Hence, the finding envisages the promising use of $\mathrm{G} / \mathrm{A} / \mathrm{SiO}_{2}-\mathrm{M}$ support fabricated from discarded OPL as a carrier for immobilization and activation of $C R L$, in conjunction to being a good alternative source of renewable silica.
\end{abstract}

Keywords: glutaraldehyde; oil palm leaves; silica; support matrix; butyl butyrate

\section{- INTRODUCTION}

Candida rugosa lipase (CRL) is a versatile biocatalyst widely used as a biocatalyst for a myriad of biotransformation processes in industries. The reasons behind this have to do with its well-reported good stereospecificity, high enantioselectivity, and stability in organic solvents, as well as possessing good thermal stability, the capability of catalyzing a plethora of important industrial reactions. Among these reactions, CRL catalyzes several reactions including hydrolysis, transesterification, esterification, and interesterification which require mild optimal working conditions through an energy-saving route [1-4]. However, like any other forms of free enzymes, the free form of CRL is vulnerable to deactivation under harsh industrial settings [5]. This shortcoming can be circumvented by the immobilization of CRL onto suitable supports, preferably those fabricated using cost-effective and renewable sources.

Resorting to using renewable and cost-effective natural polymers, for instance, rice husk [6], chitosan [7], bamboo [8] and OPL [3] to prepare matrices for biocatalysts development, is in fact, a greener technique for this purpose. Numerous studies exploring the different plant-based matrices have been reported. An earlier report [9] found that ash from hydrochloric acidtreated OPL can contain as much as $95.30 \%$ silica $\left(\mathrm{SiO}_{2}\right)$. This study is particularly interested in $\mathrm{SiO}_{2}$ following a large number of reports on its reliability as inorganic support for enzyme immobilization [10], in conjunction with its high enzyme loading capability [11]. Moreover, obtaining $\mathrm{SiO}_{2}$ from OPL may not be an issue as the biomass is readily available in large quantities throughout the year, especially in countries such as 
Indonesia and Malaysia which have vast oil palm plantations [12]. Plant-Based silica as a matrix for enzyme immobilization can be an environmentally friendly option while potentially being a source of revenue for nations.

Most importantly, immobilization of CRL onto suitable support can potentially yield many benefits, especially in improving the robustness of the lipase. In fact, the immobilization of enzymes onto matrices offers many advantages among others; i) promotes easy recovery of the catalyst from the reaction medium, ii) allows re-use of the enzyme for multiple catalytic cycles with minimal contamination of reaction product and iii) enhancing enzyme specificity and selectivity [13-14]. Aside to being cost-effective, enzyme immobilization allows the enzyme to be stored for longer duration without significant loss of activity while improving the operational stability of the enzyme in the presence of denaturing agents or under conditions of extreme $\mathrm{pH}$ and temperature [14-15]. Immobilized enzymes have been successfully employed for biosensor production [16], alongside the production of various bio-products [17-18], bioethanol and biodiesel [19], biofuel cells and bioremediation of pollutants [20]. Having said that, in this study, we proposed the use of silica derived from a renewable source, i.e., discarded oil palm leaves (OPL) as support for immobilizing and activating CRL for the purpose of catalysis.

As far as we know, studies detailing the effect of glutaraldehyde concentration on catalytic efficacy of CRL immobilized onto OPL-silica remains unreported and the feasibility of this combination has yet to be charted. It is pertinent to note that the success of an enzyme immobilization protocol depends on the degree of activation imparted by the support on the immobilized enzymes [21]. Therefore, the effect of concentration of the crosslinker on CRL immobilized onto OPL-silica should be elucidated to improve the covalent immobilization technique of the lipase on this novel plant-based matrix. A versatile crosslinker, glutaraldehyde [22] was chosen to covalently bind the primary amino groups of CRL to the surface of OPL-silica support matrix (CRL/G/A/SiO $2-\mathrm{M})$. This homobifunctional crosslinker activates the functional groups of different support matrices by linking the primary amino groups on the support surface with those of the protein molecules to be immobilized [3,4,22-24].

To test the catalytic efficacy of $\mathrm{CRL} / \mathrm{G} / \mathrm{A} / \mathrm{SiO}_{2}-\mathrm{M}$, the study used the problematic esterification production of butyl butyrate as the model reaction, as the current commercial Fisher-Speier commercial production that typically uses sulphuric acid as the catalyst produces low yields $(\sim 50 \%)$ of this ester [2,25]. In retrospect, the current synthetic method to produce butyl butyrate may be further improved by this biotechnological route by using the developed $\mathrm{CRL} / \mathrm{G} / \mathrm{A} / \mathrm{SiO}_{2}-\mathrm{M}$ as the biocatalyst. Hence, this study which evaluates the effect of glutaraldehyde concentration on the catalytic efficacy of CRL immobilized onto glutaraldehyde-activated silica from OPL becomes imperative.

\section{- EXPERIMENTAL SECTION}

\section{Materials}

Stabilized commercial CRL powder $(\geq 700 \mathrm{U} / \mathrm{mg})$ (Type VII, Sigma-Aldrich, USA), OPL, 3aminopropytriethoxysilane (APTES) solution (99\%, Sigma-Aldrich, USA), glutaraldehyde (25\%), bovine serum albumin (BSA; $\geq 96 \%$; Sigma-Aldrich, USA), $n$-butyric acid ( $\geq 99 \%$; QReC, New Zealand), 1-butanol ( $\geq$ 99\%; QReC, New Zealand), $\mathrm{NaOH}$ (QReC, New Zealand), ethyl acetate (QReC, New Zealand), phosphate buffer (100 mM, pH 7.0), toluene (QReC, New Zealand) and phenolphthalein were used in our study. All the above reagents were of analytical grade.

\section{Procedures}

\section{Extraction of $\mathrm{SiO}_{2}$ from OPL ash}

Hydrochloric acid-treated OPL as previously described [9], was calcined in Neberthern (R; Germany) furnace operating at $600^{\circ} \mathrm{C}$ for $9 \mathrm{~h}$ to produce silica-rich OPL ash. $\mathrm{SiO}_{2}$ was extracted from OPL ash using a modified method described by Johan et al. [26]. OPL ash (10.0 g) was dispersed in a $3.5 \mathrm{M} \mathrm{NaOH} \mathrm{(QReC,} \mathrm{New}$ Zealand) solution $(82.0 \mathrm{~mL})$ and refluxed in an oil bath at $100^{\circ} \mathrm{C}$ for $4 \mathrm{~h}$ under constant stirring at $200 \mathrm{rpm}$. The resultant sodium silicate solution was left to cool to room temperature, vacuum filtered using a Whatman 41 
filter paper and the filtrate stored in a capped-plastic vial until further analysis.

\section{Preparation of support}

The support was prepared by dispersing freshly prepared magnetite $(1.0 \mathrm{~g})[3]$ in deionized water $(5.0 \mathrm{~mL})$, acidified with $6.0 \mathrm{M} \mathrm{HCl}(1 \mathrm{~mL})$ and sonicated for $10 \mathrm{~min}$. In a separate plastic vial, $6.0 \mathrm{M} \mathrm{HCl}$ solution $(1.0 \mathrm{~mL})$ was added to the sodium silicate solution $(25.0 \mathrm{~mL})$ to lower the $\mathrm{pH}$ of the solution to $\mathrm{pH}$ 12.0. The acidified sodium silicate solution was transferred to the magnetite solution and further sonicated for $15 \mathrm{~min}$ before transferring into a two-necked round bottom flask. The suspension was magnetically stirred at $300 \mathrm{rpm}$ at $30{ }^{\circ} \mathrm{C}$. Hexadecyl trimethyl ammonium bromide (Sigma-Aldrich, USA) $(1.0 \mathrm{~g})$ dissolved in deionized water $(40.0 \mathrm{~mL})$ was added into the flask, and the temperature was raised to $85^{\circ} \mathrm{C}$ at a rate of $1{ }^{\circ} \mathrm{C} / \mathrm{min}$. Ethyl acetate (QReC, New Zealand) $(3.5 \mathrm{~mL})$ was rapidly added to the mixture and stirred at $600 \mathrm{rpm}$ for $15 \mathrm{~min}$ before the mixture was cooled at ambient temperature [27]. The $\mathrm{pH}$ of the mixture was adjusted to $\sim \mathrm{pH} 6.5$ by drop-wise addition of $6.0 \mathrm{M} \mathrm{HCl}$. The suspension was magnetically stirred for $12 \mathrm{~h}$ at $300 \mathrm{rpm}$ and afterward, was left to age at room temperature for a further $24 \mathrm{~h}$. The resulting composite was collected by magnetic decantation and repeatedly washed with deionized water until neutral, followed by oven drying for $2 \mathrm{~h}$ at $100{ }^{\circ} \mathrm{C}$. The dried sample was calcined at $550^{\circ} \mathrm{C}$ at a ramping temperature of $1{ }^{\circ} \mathrm{C} / \mathrm{min}$ for $5 \mathrm{~h}$ [27]. The freshly prepared composite was harvested and stored in a capped plastic vial for further analysis.

\section{Functionalization and activation of silica-magnetite (SiO $\left.{ }_{2}-\mathrm{M}\right)$ support with 3-aminopropytriethoxysilane (APTES) and glutaraldehyde (G)}

The procedure described by Gunda et al. [23] was adopted with some modifications. Under fast stirring at $500 \mathrm{rpm}$, APTES solution (99\%, Sigma-Aldrich, USA) $(1.0 \mathrm{~mL})$ was added by drop-wise into a two-necked round-bottomed flask $(250.0 \mathrm{~mL})$ containing preheated dry toluene (QReC, New Zealand) (50.0 mL). Then, $\mathrm{SiO}_{2}-\mathrm{M}$ $(1.0 \mathrm{~g})$ was dispersed in the APTES solution and refluxed at $85^{\circ} \mathrm{C}$ with stirring at $180 \mathrm{rpm}$ for $16 \mathrm{~h}$. The resulting functionalized support $\left(\mathrm{A} / \mathrm{SiO}_{2}-\mathrm{M}\right)$ were left to cool to room temperature and the supernatant decanted. The
$\mathrm{A} / \mathrm{SiO}_{2}-\mathrm{M}$ was rinsed with dry toluene and diethyl ether consecutively to remove unbound APTES, vacuum filtered through a Whatman 41 filter paper and then dried in a desiccator for $2 \mathrm{~h}$. Next, $\mathrm{A} / \mathrm{SiO}_{2}-\mathrm{M}$ powder $(0.5 \mathrm{~g})$ was dispersed in different concentrations of glutaraldehyde solutions (1, 2, 3, 4 and 5\%,) (v/v) dissolved in $100 \mathrm{mM}$ potassium phosphate buffer $(25.0 \mathrm{~mL}, \mathrm{pH} 7.0)$ and stirred at $180 \mathrm{rpm}$ for $4 \mathrm{~h}$ at room temperature. The activated silica $\left(\mathrm{G} / \mathrm{A} / \mathrm{SiO}_{2}-\mathrm{M}\right)$ were washed three times with $5 \mathrm{~mL}$ potassium phosphate buffer $(100 \mathrm{mM}, \mathrm{pH}$ 7.0), followed by vacuum filtration and left to dry in a desiccator for $16 \mathrm{~h}$. The resultant $\mathrm{G} / \mathrm{A} / \mathrm{SiO}_{2}-\mathrm{M}$ supports were stored in a capped vial until further analysis.

\section{Ninhydrin test}

The non-reacted amine groups on $\mathrm{G} / \mathrm{A} / \mathrm{SiO}_{2}-\mathrm{M}$ were subjected to ninhydrin test as described in the literature [21], with slight modifications. Ninhydrin solution was prepared by dissolving ninhydrin powder (100 mg) in a solvent system that consisted of butanol $(50.0 \mathrm{~mL})$, acetic acid $(250.0 \mu \mathrm{L})$ and deionized water $(2.3 \mathrm{~mL})$. In a capped vial, ninhydrin solution $(400.0 \mu \mathrm{L})$ was homogenized with deionized water $(200.0 \mu \mathrm{L})$. $\mathrm{A} / \mathrm{SiO}_{2}-\mathrm{M}(20.0 \mathrm{mg})$ were dispersed in the solution above and refluxed at $100{ }^{\circ} \mathrm{C}$ for $30 \mathrm{~min}$ before cooling to room temperature. The same procedure was repeated for $\mathrm{G} / \mathrm{A} / \mathrm{SiO}_{2}-\mathrm{M}$. To each sample, 50:50 (v/v) ethanol/water system $(5.0 \mathrm{~mL})$ was added, the suspension homogenized and left to stand to form the Ruhemann's purple coloration. The absorbance of each sample was read at $570 \mathrm{~nm}$, and the percentage of amino group present on the $\mathrm{G} / \mathrm{A} / \mathrm{SiO}_{2}-\mathrm{M}$ was determined using Eq. (1).

$\mathrm{P}(\%)=\frac{\mathrm{A}}{\mathrm{B}} \times 100$

where $\mathrm{P}(\%)$ is a percentage of $\mathrm{NH}_{2}$ group on the surface of the $\mathrm{G} / \mathrm{A} / \mathrm{SiO}_{2}-\mathrm{M} ; \mathrm{A}$ is the absorbance of the ninhydrin reagent $/ \mathrm{G} / \mathrm{A} / \mathrm{SiO}_{2}-\mathrm{M} ; \mathrm{B}$ is the absorbance of ninhydrin reagent $/ \mathrm{A} / \mathrm{SiO}_{2}-\mathrm{M}$.

\section{Purification and immobilization of CRL onto $\mathrm{G} / \mathrm{A} / \mathrm{SiO}_{2}-\mathrm{M}$}

Purification of CRL was carried out using the method described by Elias et al., [2] with minor modifications. In this study, $500.0 \mathrm{mg}$ of the stabilized commercial CRL powder ( $\geq 700 \mathrm{U} / \mathrm{mg}$ ) (Type VII, 
Sigma-Aldrich, USA), was freshly prepared by dissolving in $100 \mathrm{mM}$ phosphate buffer solution $(25.0 \mathrm{~mL})$ of $\mathrm{pH} 7.0$ and stirred at $200 \mathrm{rpm}$ for $10 \mathrm{~min}$. The freshly prepared CRL solution was transferred into a spin column and centrifuged at $6842.16 \times \mathrm{g}$ for $10 \mathrm{~min}$ to remove the binder (starch). The immobilization procedure described by Zhu et al. [28] was adopted with some modifications. The freshly prepared CRL solution $(20.0 \mathrm{~mL})$ was transferred into a capped vial containing $1 \%$ glutaraldehyde-activated $\mathrm{A} / \mathrm{SiO}_{2}-\mathrm{M}(1 \mathrm{~g})$ and was left stirring for $12 \mathrm{~h}$ at $180 \mathrm{rpm}$. The resultant $\mathrm{CRL} / \mathrm{G} / \mathrm{A} / \mathrm{SiO}_{2}-\mathrm{M}$ were vacuum filtered through a Whatman 41 filter paper and washed with copious amounts of $100 \mathrm{mM}$ phosphate buffer solution ( $\mathrm{pH}$ 7.0) to remove any unbound lipase. The resultant $\mathrm{CRL} / \mathrm{G} / \mathrm{A} / \mathrm{SiO}_{2}-\mathrm{M}$ were air-dried in a desiccator for $12 \mathrm{~h}$ and stored at $4{ }^{\circ} \mathrm{C}$ until further use. The above procedure was repeated for 2, 3, 4 and $5 \%(\mathrm{v} / \mathrm{v})$ glutaraldehydeactivated $\mathrm{A} / \mathrm{SiO}_{2}-\mathrm{M}$ and $4 \%(\mathrm{v} / \mathrm{v})$ glutaraldehydeactivated $\mathrm{A} / \mathrm{SiO}_{2}-\mathrm{M}$ dispersed in toluene $(5 \mathrm{~mL})$. All CRL solutions were freshly prepared in this study.

\section{Determination of protein loading, immobilized yield, and lipase activity}

Quantification of protein in the enzyme solution, before and after the immobilization was carried out by the Bradford method, which used bovine serum albumin (BSA; $\geq 96 \%$; Sigma-Aldrich, USA) as the protein standard and Bradford reagent protein-dye [29]. The loading capacity of immobilized protein (IP) was calculated based on the difference between the initial and final protein concentrations in the prepared immobilization solution (mg/g of support) (Eq. (2)) while the immobilization yield was calculated based on Eq. (3).

$$
\begin{aligned}
& \text { IP }(\mathrm{mg} / \mathrm{g})=\frac{\mathrm{C}_{\mathrm{i}} \mathrm{V}_{\mathrm{i}}-\left(\mathrm{C}_{\mathrm{s}} \mathrm{V}_{\mathrm{s}}+\mathrm{C}_{\mathrm{w}} \mathrm{V}_{\mathrm{w}}\right)}{\mathrm{W}} \\
& \mathrm{IY}(\mathrm{mg} / \mathrm{g})=\frac{\mathrm{C}_{\mathrm{i}} \mathrm{V}_{\mathrm{i}}-\left(\mathrm{C}_{\mathrm{s}} \mathrm{V}_{\mathrm{s}}+\mathrm{C}_{\mathrm{w}} \mathrm{V}_{\mathrm{w}}\right)}{\mathrm{C}_{\mathrm{i}} \mathrm{V}_{\mathrm{i}}} \times 100
\end{aligned}
$$

where, IP is the amount of CRL loaded on the support $\left(\mathrm{mg}_{\text {protein }} / \mathrm{g}_{\text {support }}\right)$; IY refers to the immobilization yield (\%); $\mathrm{C}_{\mathrm{i}}, \mathrm{C}_{\mathrm{s}}$, and $\mathrm{C}_{\mathrm{w}}$ are the protein concentration $(\mathrm{mg} / \mathrm{mL})$ of initial, supernatant and wash solutions of CRL, respectively; $\mathrm{V}_{\mathrm{i}}, \mathrm{V}_{\mathrm{s}}$, and $\mathrm{V}_{\mathrm{w}}$ are the volumes $(\mathrm{mL})$ of initial, supernatant and wash solutions of CRL, respectively and $\mathrm{W}$ is the weight of support ( $\mathrm{g}$ ).
Esterification activity was estimated based on the esterification reaction of $n$-butyric acid ( $\geq 99 \%$; QReC, New Zealand) and 1-butanol ( $\geq 99 \%$; QReC, New Zealand) catalyzed by $\mathrm{CRL} / \mathrm{G} / \mathrm{A} / \mathrm{SiO}_{2}-\mathrm{M}$. For the enzymatic reaction, a standard reaction was carried out in $15 \mathrm{~mL}$ screw-capped vial which comprised of $n$ butyric acid and 1-butanol (1:2) stirred in $n$-heptane (200 rpm) at $45^{\circ} \mathrm{C}$ for $3 \mathrm{~h}$. A blank containing $300 \mu \mathrm{L}$ of the reaction mixture without the enzyme was titrated to determine the initial total acid content. Lipase activity was estimated using Eq. (4). One international unit of activity is defined as $1 \mu \mathrm{mol}$ of butyric acid consumed in the esterification per min (1 IU) under assay conditions. All determinations were performed in triplicates.

Esterificationactivity $\left(\mathrm{U} / \mathrm{g}_{\text {protein }}\right)=\frac{\left(\mathrm{V}_{\mathrm{o}}-\mathrm{V}_{\mathrm{i}}\right) \times \mathrm{M} \times 1000}{\mathrm{E} \times \mathrm{T}}$

where $\mathrm{V}_{\mathrm{o}}$ and $\mathrm{V}_{\mathrm{i}}=$ Volumes $(\mathrm{mL})$ of $\mathrm{NaOH}$ used to neutralize unreacted butyric acid in the reaction mixture without and with CRL, respectively. $\mathrm{M}=$ Concentration $(\mathrm{mol} / \mathrm{L})$ of $\mathrm{NaOH}$. $\mathrm{E}=$ Weight $(\mathrm{g})$ of protein in $\mathrm{CRL} / \mathrm{G} / \mathrm{A} / \mathrm{SiO}_{2}-\mathrm{M}$. T $=$ Time $(\mathrm{min})$ of incubation.

\section{Purification of butyl butyrate and product characterization}

The procedure described by Elias et al. [2] was adopted with minor modifications. In the present work, the biocatalysts $\left(\mathrm{CRL} / \mathrm{G} / \mathrm{A} / \mathrm{SiO}_{2}-\mathrm{M}\right)$ were removed from the reaction mixture by vacuum filtration through a Whatman 41 filter paper. The unreacted butyric acid in the reaction mixture was removed by vigorously shaking the mixture in a separating funnel that contained $10 \mathrm{~mL}$ of $\mathrm{NaOH}$ solution $(50 \mathrm{mM})$. It was allowed to stand for $10 \mathrm{~min}$, and the aqueous layer was a run-off. The above procedure was repeated twice. Calcium chloride $\left(\mathrm{CaCl}_{2}\right)$ solution ( $8 \mathrm{~g}$ in $10 \mathrm{~mL}$ of distilled water) was added to the remaining organic layer in the funnel, and the mixture was shaken vigorously. The resultant aqueous layer was run off. The mixture of 1-butanol and butyl butyrate was dried over anhydrous magnesium sulfate $\left(\mathrm{MgSO}_{4}\right)(200$ $\mathrm{mg}$ ) and vacuum filtered as above. The unreacted 1butanol (bp. $117^{\circ} \mathrm{C}$ ) was distilled out of the mixture by rotary evaporation under vacuum at $80{ }^{\circ} \mathrm{C}$ in a $50 \mathrm{~mL}$ round-bottomed flask, leaving pure butyl butyrate (bp. 
$165{ }^{\circ} \mathrm{C}$ ) in the flask. The purified butyl butyrate was collected and stored in capped vials for further analysis.

$\mathrm{CRL} / \mathrm{G} / \mathrm{A} / \mathrm{SiO}_{2}-\mathrm{M}$ prepared using the various glutaraldehyde concentrations and the esterification production catalyzed by $\mathrm{CRL} / \mathrm{G} / \mathrm{A} / \mathrm{SiO}_{2}-\mathrm{M}$ were characterized using Fourier transform infrared (FTIR) and proton nuclear magnetic resonance $\left({ }^{1} \mathrm{H}\right.$ NMR) as described below.

Fourier transform infrared (FTIR) - attenuated total reflection (ATR). FTIR-ATR spectra for $\mathrm{G} / \mathrm{A} / \mathrm{SiO}_{2}-\mathrm{M}$ and the produced butyl butyrate at $0 \mathrm{~h}, 3 \mathrm{~h}$ as well as the purified ester were recorded on a 100 FTIR spectrometer (Perkin-Elmer Inc., Norwalk, USA) using one-bounce ATR mode. Each sample was placed on a diamond/ZnSe crystal plate, and the spectra were obtained at room temperature in transmission mode in the range of 4000$400 \mathrm{~cm}^{-1}$ at a resolution of $4 \mathrm{~cm}^{-1}$. To ensure accuracy, spectral readings were taken in triplicates.

\section{Proton nuclear magnetic resonance ( ${ }^{1} \mathrm{H}$ NMR).} Purified butyl butyrate was dissolved in deuterated chloroform $\left(\mathrm{CDCl}_{3}\right)$, and its structure was elucidated using a ${ }^{1} \mathrm{H}$ NMR (Bruker Avance III-HD, $700 \mathrm{MHz}$ ) spectrometer operating on a $5 \mathrm{~mm}$ probe at $25^{\circ} \mathrm{C}$ and the spectra were recorded in 16 transients. The experiment was performed at $298 \mathrm{~K}$ with $32 \mathrm{~K}$ complex points and a pulse length of $45^{\circ}$. A total of 128 scans of $8417 \mathrm{~Hz}$ spectral width was acquired within $3.8 \mathrm{sec}$ duration.

\section{- RESULTS AND DISCUSSION}

\section{Efficacy of Support Activation}

The success of an enzyme immobilization protocol depends on the degree of activation imparted by the support of the immobilized enzymes [20]. Hence, the ninhydrin test was conducted by the study to establish the extent of activation conferred by the $\mathrm{A} / \mathrm{SiO}_{2}-\mathrm{M}$ or $\mathrm{G} / \mathrm{A} / \mathrm{SiO}_{2}-\mathrm{M}$ on the immobilized CRL.

\section{Ninhydrin test}

The success of an enzyme immobilization protocol depends on the degree of activation imparted by the support of the immobilized enzyme [21]. Hence, the ninhydrin test was conducted in the present study to establish the extent of activation conferred by glutaraldehyde on the surface of $\mathrm{A} / \mathrm{SiO}_{2}-\mathrm{M}$. Comparison between the various glutaraldehyde treatments on $\mathrm{A} / \mathrm{SiO}_{2}-\mathrm{M}$ clearly indicated that the treatment with $1 \%$ $(\mathrm{v} / \mathrm{v})$ glutaraldehyde resulted in the lowest surface activation (Fig. 1) and retained $60.5 \%$ of $\mathrm{NH}_{2}$ groups on the surface of $\mathrm{G} / \mathrm{A} / \mathrm{SiO}_{2}-\mathrm{M}$. This was followed by treatments with the 5,2 and $3 \%(\mathrm{v} / \mathrm{v})$ percent concentrations of glutaraldehyde which gave 59.0, 49.7 and $48.0 \%$ of remaining $\mathrm{NH}_{2}$ groups, respectively. High retention of surface $\mathrm{NH}_{2}$ groups for the $1 \%(\mathrm{v} / \mathrm{v})$ glutaraldehyde treatment on $\mathrm{A} / \mathrm{SiO}_{2}-\mathrm{M}$ observed here correlates well with the lower availability of glutaraldehyde for interaction with $\mathrm{A} / \mathrm{SiO}_{2}-\mathrm{M}$, conveying that much of the surface $\mathrm{NH}_{2}$ groups on $\mathrm{G} / \mathrm{A} / \mathrm{SiO}_{2}-\mathrm{M}$ did not undergo Schiff s base reaction to form imine bonds $(\mathrm{C}=\mathrm{N})$ with glutaraldehyde. This, in turn, resulted in fewer activated sites on $\mathrm{A} / \mathrm{SiO}_{2}-\mathrm{M}$ for bonding with $\mathrm{CRL}$.

Conversely, $\mathrm{A} / \mathrm{SiO}_{2}-\mathrm{M}$ treated with $4 \%(\mathrm{v} / \mathrm{v})$ glutaraldehyde gave $\mathrm{G} / \mathrm{A} / \mathrm{SiO}_{2}-\mathrm{M}$ with the lowest concentration of surface $\mathrm{NH}_{2}$ groups that corresponded to $37.6 \%$. It proved that $4 \%(\mathrm{v} / \mathrm{v})$ glutaraldehyde was optimal to achieve the highest percentage of activation sites on $\mathrm{A} / \mathrm{SiO}_{2}-\mathrm{M}$ for $\mathrm{CRL}$ binding; thus this concentration was adopted in the subsequent process to immobilize $\mathrm{CRL}$ on $\mathrm{A} / \mathrm{SiO}_{2}-\mathrm{M}$.

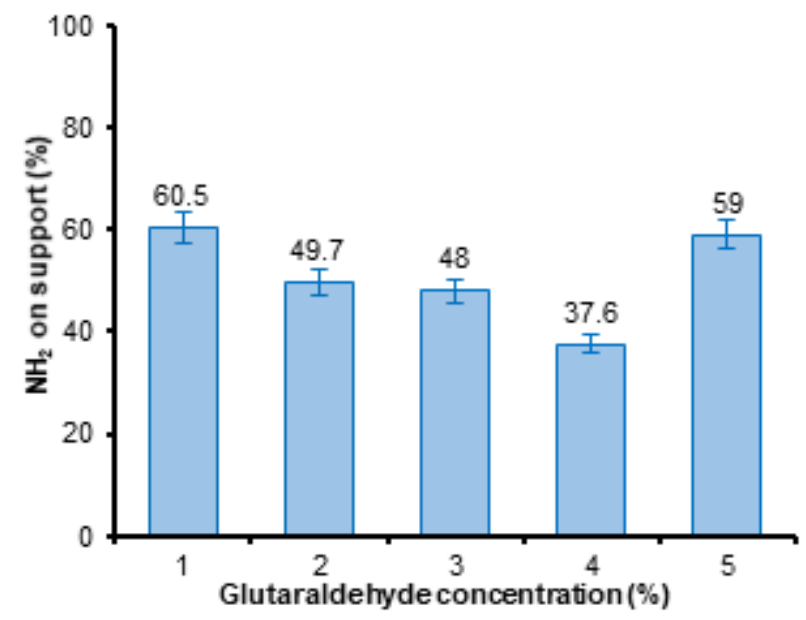

Fig 1. Ninhydrin test showing the percentage of $\mathrm{NH}_{2}$ groups on $\mathrm{G} / \mathrm{A} / \mathrm{SiO}_{2}-\mathrm{M}$ after activation with glutaraldehyde 


\section{FTIR analysis of $\mathrm{G} / \mathrm{A} / \mathrm{SiO}_{2}-\mathrm{M}$}

FTIR analysis is essential to monitor the effect of concentration of glutaraldehyde to prepare and immobilize $\mathrm{CRL}$ onto $\mathrm{G} / \mathrm{A} / \mathrm{SiO}_{2}-\mathrm{M}$. FTIR spectra for all the various stages of activation (Fig. 2) showed typical broadband at $3420 \mathrm{~cm}^{-1}$ associated with the $-\mathrm{OH}$ stretching vibration which originated from the silanol $(\mathrm{Si}-\mathrm{OH})$ groups and trapped water molecules. Intense bands at 1108, 796 and $472 \mathrm{~cm}^{-1}$ were attributed to the asymmetric stretching, symmetric stretching and deformation modes of siloxane group (Si-O-Si), respectively. Similar vibrational stretching was also reported by other studies describing hierarchical porous silica obtained from tetraethyl orthosilicate (TEOS) as silica source [30], and those reported for mesoporous $\mathrm{SiO}_{2}$ particles [31-32]. The $-\mathrm{CH}_{2}$ stretching mode of the hydrocarbon skeleton observed at $2954 \mathrm{~cm}^{-1}$ in all the spectra (Fig. 2), agreed well with a report by Majoul et al. [33] that used FTIR to investigate the progress of porous silicon functionalized with APTES.

All spectra (Fig. 2) revealed bands at 1556 and $1454 \mathrm{~cm}^{-1}$ that originated from the symmetric and nonsymmetric stretching vibrations of $\mathrm{N}-\mathrm{H}$ of the primary amine from APTES as described in the literature [30].
However, intensities of both bands marginally decreased with increasing concentration of glutaraldehyde from $1 \%$ (Fig. 2(a)) to $4 \%$ (Fig. 2(d)), as more molecules of glutaraldehyde are present in the preparation. A band at $1642 \mathrm{~cm}^{-1}$ in all the spectra (Fig. 2) corresponds to the $\mathrm{C}=\mathrm{O}$ stretching vibration resulting from interactions between APTES and glutaraldehyde, suggesting that the support was successfully activated with glutaraldehyde, as similarly described by Gunda et al. [23]. Observably, intensity of this band increased with elevated concentrations of glutaraldehyde solutions from $1 \%$ (Fig. 2(a)) to 4\% (Fig. 2(d)), whereas further increases in concentrations of glutaraldehyde beyond $4 \%(\mathrm{v} / \mathrm{v})$ was seen as counterproductive (Fig. 2(e)), as clearly shown in the ninhydrin test when the percentage of $\mathrm{NH}_{2}$ groups on $\mathrm{G} / \mathrm{A} / \mathrm{SiO}_{2}-\mathrm{M}$ began to increase again (Fig. 1). Hence, $4 \%(\mathrm{v} / \mathrm{v})$ glutaraldehyde concentration was adopted as the optimum concentration to activate OPL derived silica for lipase immobilization.

\section{Effect of glutaraldehyde concentration}

The effect of glutaraldehyde concentration on the immobilization efficacy of CRL onto $\mathrm{G} / \mathrm{A} / \mathrm{SiO}_{2}-\mathrm{M}$ was assessed as described in the Experimental Section. Data

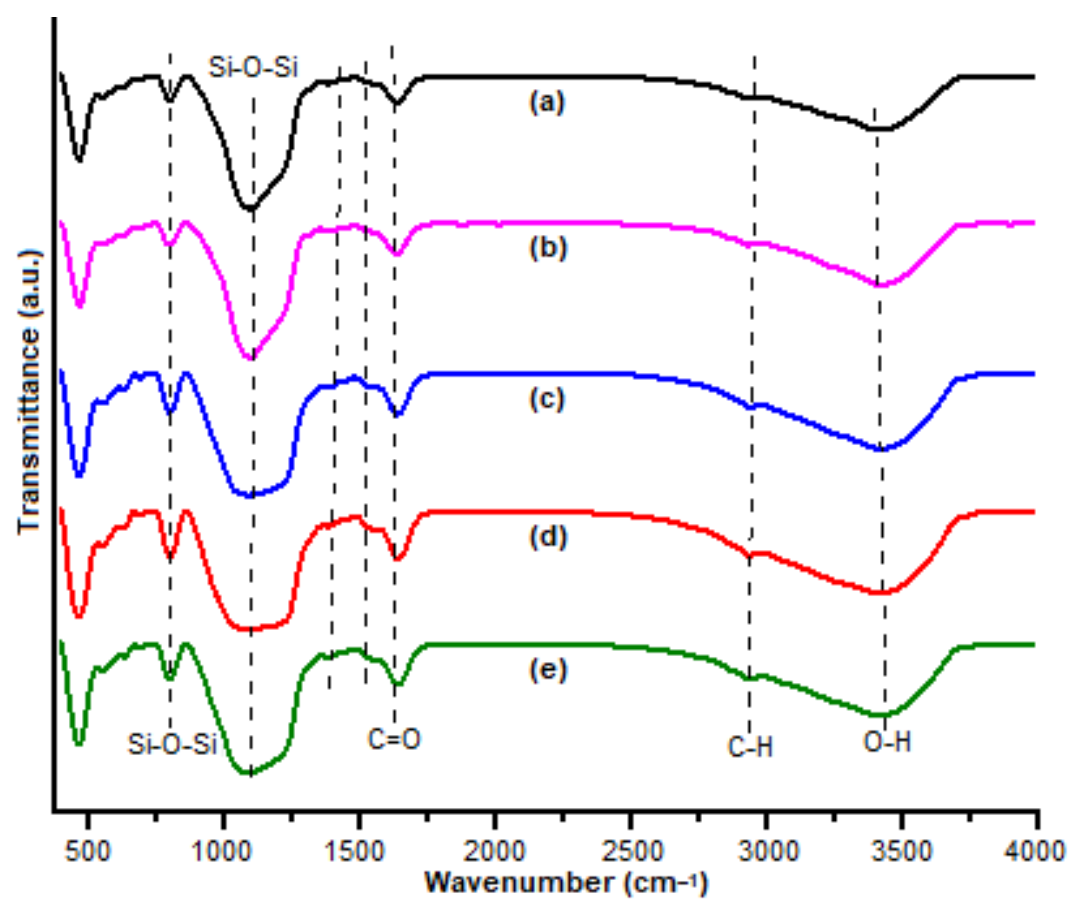

Fig 2. FTIR analysis of $\mathrm{G} / \mathrm{A} / \mathrm{SiO}_{2}-\mathrm{M}$ prepared using different concentrations of glutaraldehyde solutions. (a) $1 \%$ (v/v), (b) $2 \%(\mathrm{v} / \mathrm{v}),(\mathrm{c}) 3 \%(\mathrm{v} / \mathrm{v}),(\mathrm{d}) 4 \%(\mathrm{v} / \mathrm{v})$ and (e) $5 \%(\mathrm{v} / \mathrm{v})$ 
on CRL protein loading (Fig. 3(a)) agreed well with the results of the ninhydrin test in Fig. 1 and FTIR (Fig. 2). The inverse correlation between results of the ninhydrin test and protein loading for enzyme immobilization was clearly demonstrated. The highest protein loading of $68.3 \mathrm{mg} / \mathrm{g}$ was observed for $\mathrm{G} / \mathrm{A} / \mathrm{SiO}_{2}-\mathrm{M}$ activated using $4 \%(\mathrm{v} / \mathrm{v})$ glutaraldehyde that was pre-treated with toluene during CRL immobilization (Fig. 3(a)). The data corroborate the use of a hydrophobic solvent in an enzyme immobilization protocol being crucial in inducing the lid opening' phenomenon. Literature has shown that this additional treatment transforms the lipase into a 'frozen' active state (open conformation) on the surface of the support [14]. Our observation is in agreement with similar studies of earlier researchers [34-36]. Subsequent protein loadings were lower as the supports were not pretreated with toluene. The second highest protein loading at $48 \mathrm{mg} / \mathrm{g}$ was obtained with the use of $4 \%$ glutaraldehyde followed by $3 \%(44.0 \mathrm{mg} / \mathrm{g}), 2 \%(42.6 \mathrm{mg} / \mathrm{g})$,
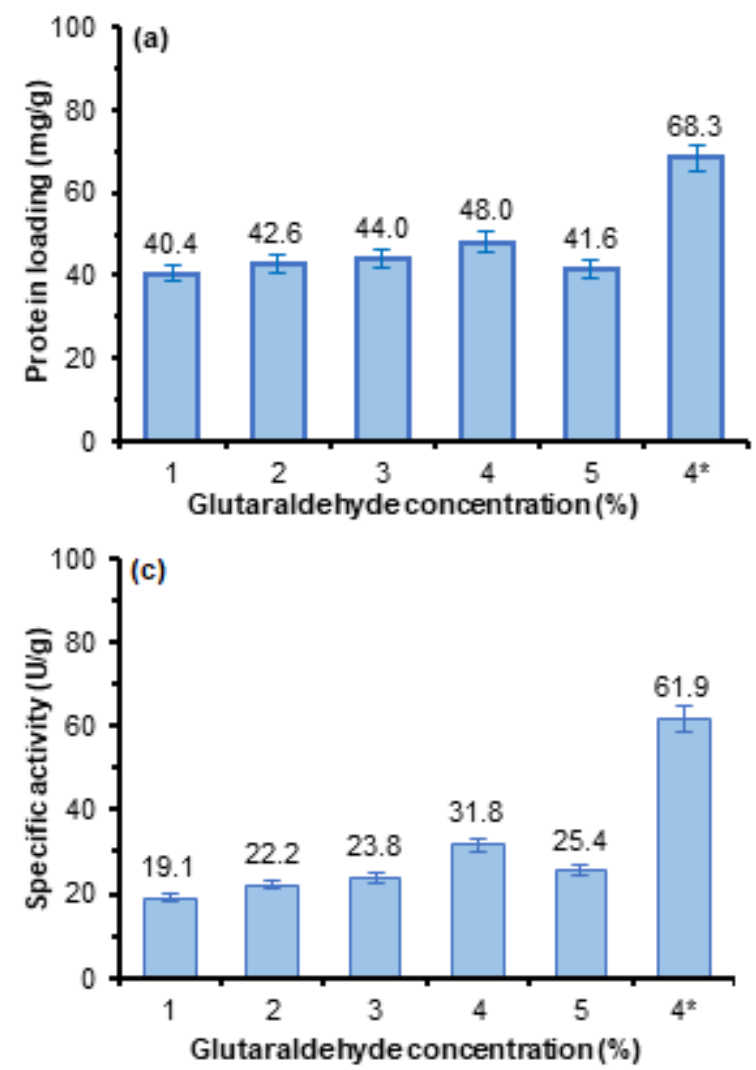

$5 \%(41.6 \mathrm{mg} / \mathrm{g})$, and the lowest was at $1 \%(\mathrm{v} / \mathrm{v})$ of glutaraldehyde (40.4 mg/mg) (Fig. 3(a)). The study would like to highlight that, the highest immobilization yield of $\mathrm{CRL}$ on $\mathrm{G} / \mathrm{A} / \mathrm{SiO}_{2}-\mathrm{M}$ at $74.3 \%$ (Fig. 3(b)) correlated well with data of the best outcomes in the ninhydrin test $(37.6 \%)$ and protein loading $(68.3 \mathrm{mg} / \mathrm{g})$ for $\mathrm{G} / \mathrm{A} / \mathrm{SiO}_{2}-\mathrm{M}$ activated in $4 \%(\mathrm{v} / \mathrm{v})$ glutaraldehyde pre-treated with toluene. A similar observation was also reported by Spinelli et al. [21]. These best conditions to prepare the $\mathrm{CRL} / \mathrm{G} / \mathrm{A} / \mathrm{SiO}_{2}-\mathrm{M}$ yielded the highest specific activity and percent yield of butyl butyrate at $61.9 \mathrm{U} / \mathrm{mg}$ and $76.5 \%$, respectively, in just $3 \mathrm{~h}$ of reaction. Consequently, $\mathrm{CRL} / \mathrm{G} / \mathrm{A} / \mathrm{SiO}_{2}-\mathrm{M}$ prepared under similar conditions without pre-treatment in toluene was the second best, and gave immobilization yield, specific activity and percent yield of butyl butyrate at $55.7 \%$ (Fig. 3(b)), 31.8 U/mg (Fig. 3(c)) and $40.0 \%$ (Fig. 3(d)), respectively.

Results for subsequent protein loading (Fig. 3(a)),
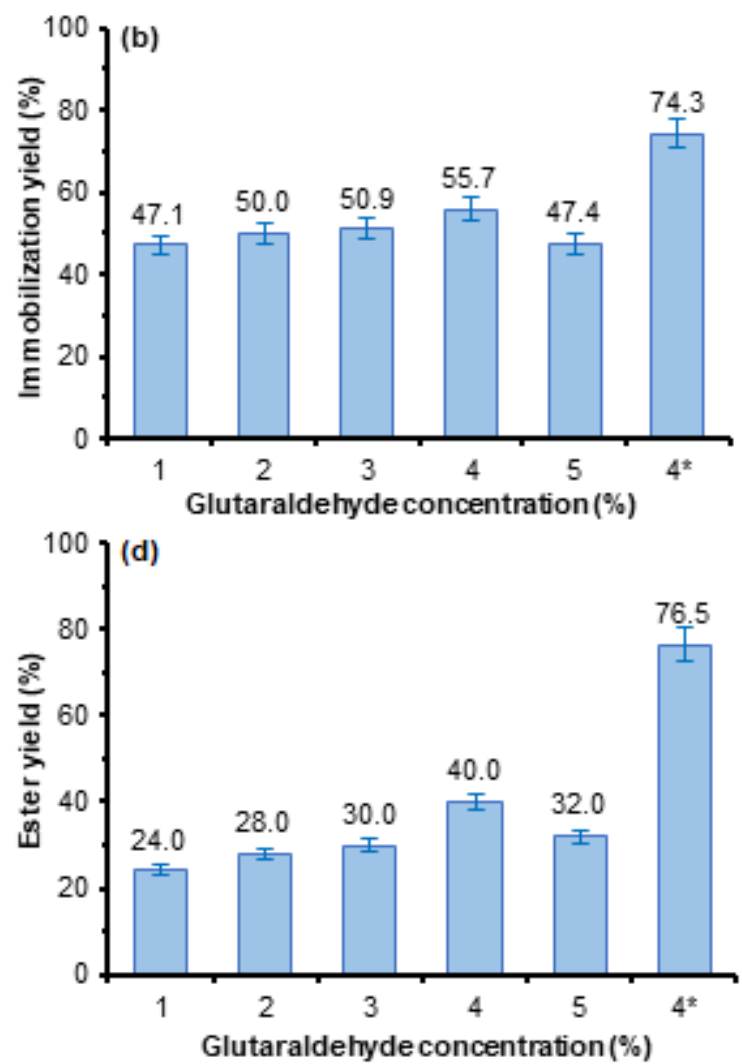

Fig 3. Effect of glutaraldehyde concentration on immobilization efficiency of CRL onto $\mathrm{G} / \mathrm{A} / \mathrm{SiO}_{2}-\mathrm{M}$. (a) Protein loading, (b) immobilization yield, (c) specific activity and (d) yield of butyl butyrate. Note: $4^{\star}$ indicates that $4 \%$ $\mathrm{G} / \mathrm{A} / \mathrm{SiO}_{2}-\mathrm{M}$ were dispersed in toluene before immobilization 
immobilization yield (Fig. 3(b)), specific activity (Fig. 3(c)) and percent of produced butyl butyrate (Fig. 3(d)) was seen to follow a declining order of concentrations of glutaraldehyde (v/v) at $3 \%(44.0 \mathrm{mg} / \mathrm{g}, 50.9 \%, 23.8 \mathrm{U} / \mathrm{mg}$, $30.0 \%$ ), $2 \%$ ( $42.6 \mathrm{mg} / \mathrm{g}, 50.0 \%, 22.2 \mathrm{U} / \mathrm{mg}, 28.0 \%$ ), 5\% (41.6 mg/g, 47.4\%, $25.4 \mathrm{U} / \mathrm{mg}, 32.0 \%$ ) and lastly, $1 \%$ (40.4 mg/g, 47.1\%, $19.1 \mathrm{U} / \mathrm{mg}, 24.0 \%$ ). Characteristically, all results consistently demonstrated that catalytic attributes of the $\mathrm{CRL} / \mathrm{G} / \mathrm{A} / \mathrm{SiO}_{2}-\mathrm{M}$ (protein loading, immobilization yield, specific activity and ester yield) improved when glutaraldehyde concentrations were elevated from 1 to $4 \%$ before a decline was observed. $\mathrm{G} / \mathrm{A} / \mathrm{SiO}_{2}-\mathrm{M}$ pre-treated with toluene consistently gave the best results.

It is worth mentioning here that pre-treatment of $\mathrm{G} / \mathrm{A} / \mathrm{SiO}_{2}-\mathrm{M}$ with toluene during the immobilization process ensured that CRL molecules were immobilized in their predominant open form or active conformation on the surface of $\mathrm{G} / \mathrm{A} / \mathrm{SiO}_{2}-\mathrm{M}$. It is described in the literature that the presence of a hydrophobic solvent, i.e., toluene will induce the displacement and opening of the lid of CRL that conceals the entrance into the active site. This mechanism is typically called interfacial activation. Toluene molecules bind to the hydrophobic lid of CRL and trigger the lid to open. This facilitates access of the substrates into the active site of the lipase, thereby resulting in higher lipase activity and immobilization efficiency [36]. The outcome seen in this study is consistent with the findings reported in the literature [3738] for lipase immobilization that also uses a hydrophobic solvent to activate the lipase. Likewise, it also indicated the imperative role of toluene in modulating and accomplishing the best conformation for immobilizing $\mathrm{CRL}$ onto $\mathrm{G} / \mathrm{A} / \mathrm{SiO}_{2}-\mathrm{M}$. Hence, it is shown that pretreatment of $\mathrm{G} / \mathrm{A} / \mathrm{SiO}_{2}-\mathrm{M}$ in toluene during $\mathrm{CRL}$ immobilization was a key factor in ensuring high activity of $\mathrm{CRL} / \mathrm{G} / \mathrm{A} / \mathrm{SiO}_{2}-\mathrm{M}$. The highest protein load and immobilization yield were seen in this study also corroborate the abovementioned attainment of maximum enzyme specific activity and yield of butyl butyrate by $\mathrm{CRL} / \mathrm{G} / \mathrm{A} / \mathrm{SiO}_{2}-\mathrm{M}$. Perspectively, it is affirmed that a $4 \%(\mathrm{v} / \mathrm{v})$ glutaraldehyde concentration followed by pre-treatment in toluene was crucial for activating APTES functionalized OPL-derived silica, as a carrier for CRL immobilization.

\section{Product Identification}

\section{FTIR spectroscopy}

FTIR-ATR spectra for reaction mixtures at $0 \mathrm{~h}, 3 \mathrm{~h}$ as well as the purified ester product are shown in Fig. 4. A broad peak at $3449 \mathrm{~cm}^{-1}$ (Fig. 4(a)) typically assigned to the $\mathrm{O}-\mathrm{H}$ stretching vibrations for carboxylic acid was absent in the spectra for the $3 \mathrm{~h}$ esterification samples (Fig. 4(b)), as well as in the purified butyl butyrate (Fig. 4(c)). The peak for $\mathrm{C}=\mathrm{O}$ at $1714 \mathrm{~cm}^{-1}$ for the butyric acid dimer shifted to higher wavenumbers namely, $1740 \mathrm{~cm}^{-1}$ (Fig. 4(b)) and $1737 \mathrm{~cm}^{-1}$ (Fig. 4(c)) [39], for samples of the $3 \mathrm{~h}$ incubation and the purified reaction mixture, respectively, were characteristic for the presence of the ester. Multiple peaks corresponding to 1090, 1180 and $1255 \mathrm{~cm}^{-1}$ (Fig. 4(c)), typical of C-O-C stretching vibrations of ester were also visible, though less prominent, in the spectrum of the $3 \mathrm{~h}$ incubation mixture (Fig. 4(b)) but were absent in Fig. 4(a). The results were supportive of butyl butyrate being produced by the $\mathrm{CRL} / \mathrm{G} / \mathrm{A} / \mathrm{SiO}_{2}-\mathrm{M}$ catalyzed esterification reaction.

\section{Proton nuclear magnetic resonance ( ${ }^{1} H$ NMR)}

${ }^{1} \mathrm{H}$ NMR spectrum of ester produced in the $\mathrm{CRL} / \mathrm{G} / \mathrm{A} / \mathrm{SiO}_{2}-\mathrm{M}$ catalyzed the esterification of 1-butanol, and butyric acid depicted 16 protons that were characteristic for butyl butyrate (CAS: 109-21-7) (Fig. 5). Signals at chemical shifts $\delta(\mathrm{ppm}) 0.94(3 \mathrm{H}, \mathrm{t}$, $\left.-\mathrm{CH}_{3}\right), 0.96\left(3 \mathrm{H}, \mathrm{t},-\mathrm{CH}_{3}\right), 1.39\left(2 \mathrm{H}, \mathrm{s},-\mathrm{CH}_{2}\right), 1.57(2 \mathrm{H}, \mathrm{s}$, $\left.-\mathrm{CH}_{2}\right), 1.67\left(2 \mathrm{H}, \mathrm{q},-\mathrm{CH}_{2}\right), 2.26\left(2 \mathrm{H}, \mathrm{t},-\mathrm{CH}_{2}\right)$, and 4.05 $\left(2 \mathrm{H}, \mathrm{t},-\mathrm{OCH}_{2}\right)$ are allotted to methyl, methylene and oxylmethylene protons, respectively. The oxylmethylene protons ' $\mathrm{a}$ ', $(\delta=4.05 \mathrm{ppm})$ was the most de-shielded proton that resulted from the high electronegative effect of oxygen. The de-shielding effect of oxygen is reduced in proton ' $b$ ' due to the intervening carbon, but has a much higher chemical shift $(\delta=2.26)$ as compared to other methylene protons present in the compound. This is due to the moderately high electronegativity of the adjacent $\mathrm{C}=\mathrm{O}$ carbon. The electronegativity effect of the heteroatom (oxygen) in the compound reduces along the chain, with the methylene protons ' $c$ ', ' $d$ ' and ' $e$ ' 


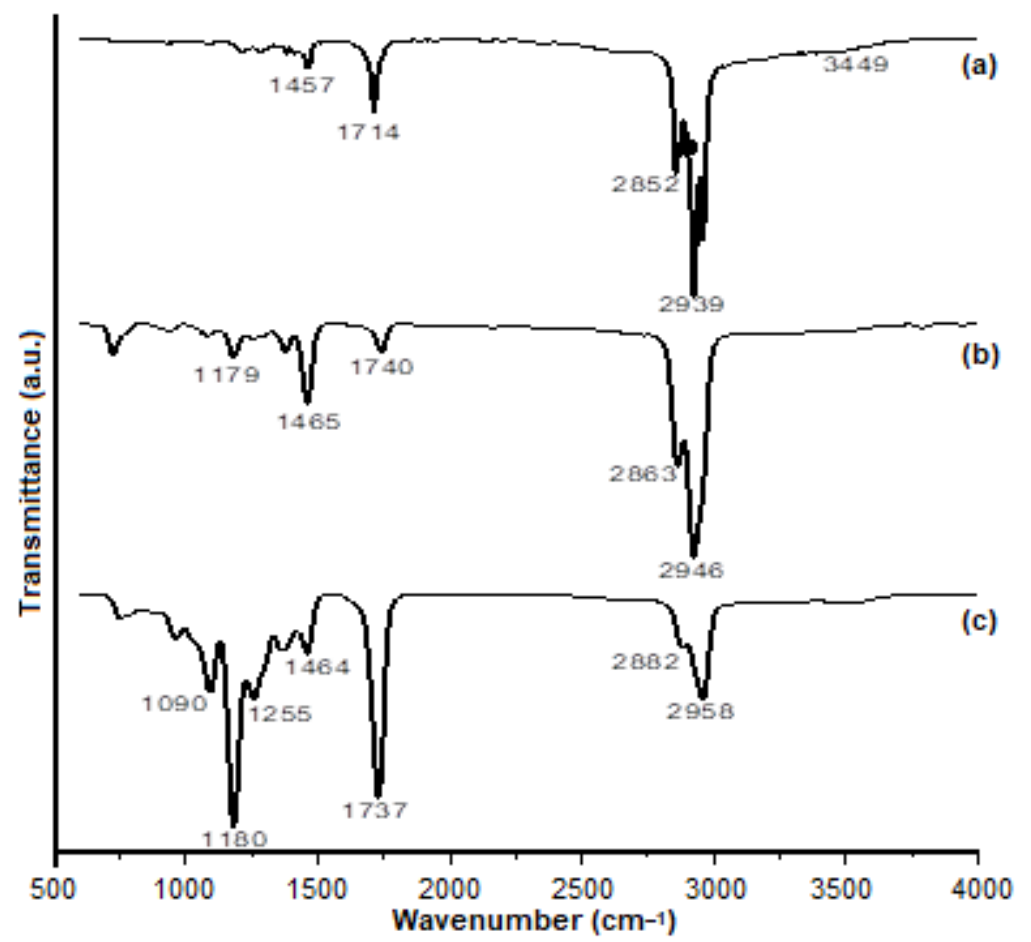

Fig 4. FTIR spectra for reaction mixtures at (a) $0 \mathrm{~h}$ and (b) $3 \mathrm{~h}$, as well as (c) purified butyl butyrate

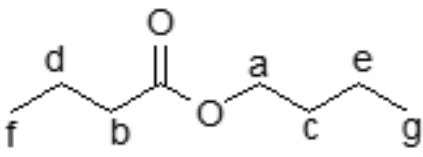

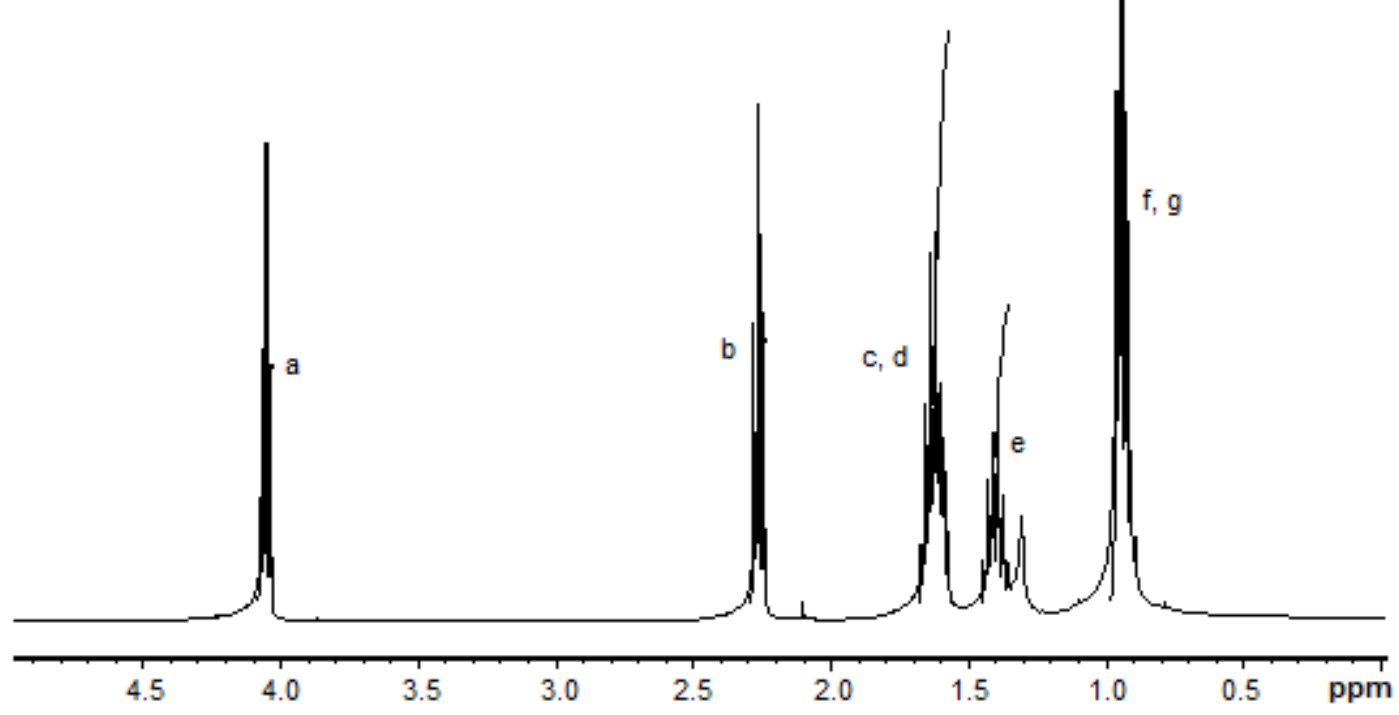

Fig 5. ${ }^{1} \mathrm{H}$ NMR spectrum of purified butyl butyrate

experiencing less de-shielding effect hence appearing at much lower chemical shifts as aforementioned.
The shielding on protons ' $\mathrm{f}$ ' and ' $\mathrm{g}$ ' resulted in lower magnetic fields as indicated by their chemical 
shifts at $\delta=0.94$ and $\delta=0.96$, respectively. The absence of a chemical shift for $\mathrm{OH}$ imperatively indicated that both alcohol and butyric acid were absent. This was indicative of a well-purified product of the enzymatic esterification reaction. The data therefore, affirmed the enzymatically produced ester was butyl butyrate and, thus complemented the data seen in FTIR analysis for purified butyl butyrate (Fig. 4(c)).

\section{- CONCLUSION}

The findings of this study demonstrated that the catalytic efficiency of CRL/G/A/SiO $2-\mathrm{M}$ improved of the protein loading, immobilization yield, specific activity and ester yield when glutaraldehyde concentrations were elevated from 1 to $4 \%(\mathrm{v} / \mathrm{v})$. Since a $4 \%$ concentration of $\mathrm{G} / \mathrm{A} / \mathrm{SiO}_{2}-\mathrm{M}$ pre-treated in toluene consistently gave the best results, this indicated the crucial role of toluene in facilitating achievement of the best conformation of CRL before immobilization onto the $\mathrm{G} / \mathrm{A} / \mathrm{SiO}_{2}-\mathrm{M}$ supports. The high protein loading and immobilization yield were seen in this study also corroborate the maximum enzyme specific activity and yield of butyl butyrate by $\mathrm{CRL} / \mathrm{G} / \mathrm{A} / \mathrm{SiO}_{2}-\mathrm{M}$. Thus, this immobilization procedure which uses a $4 \%(\mathrm{v} / \mathrm{v})$ glutaraldehyde solution for activating APTES functionalized OPL-derived silica, followed by pre-treatment in toluene, appeared favorable to prepare $\mathrm{CRL} / \mathrm{G} / \mathrm{A} / \mathrm{SiO}_{2}-\mathrm{M}$ with the highest activity.

\section{- ACKNOWLEDGMENTS}

This work was supported by the Research University Grant Scheme (Q.J130000.2526.13H09) from Universiti Teknologi Malaysia, Johor.

\section{- REFERENCES}

[1] Marzuki, N.H.C., Mahat, N.A., Huyop, F., AboulEnein, H.Y., and Wahab, R.A., 2015, Sustainable production of the emulsifier methyl oleate by Candida rugosa lipase nanoconjugates, Food Bioprod. Process., 96, 211-220.

[2] Elias, N., Chandren, S., Attan, N., Mahat, N.A., Razak, F.I.A., Jamalis, J., and Wahab, R.A., 2017, Structure and properties of oil palm-based nanocellulose reinforced chitosan nanocomposite for efficient synthesis of butyl butyrate, Carbohydr. Polym., 176, 281-292.

[3] Onoja, E., Chandren, S., Razak, F.I.A., and Wahab, R.A., 2018, Extraction of nanosilica from oil palm leaves and its application as support for lipase immobilization, J. Biotechnol., 283, 81-96.

[4] Onoja, E., Chandren, S., Razak, F.I.A., and Wahab, R.A., 2018, Enzymatic synthesis of butyl butyrate by Candida rugosa lipase supported on magnetizednanosilica from oil palm leaves: Process optimization, kinetic and thermodynamic study, $J$. Taiwan Inst. Chem. Eng., 91, 105-118.

[5] Sheldon, R.A., and van Pelt, S., 2013, Enzyme immobilisation in biocatalysis: Why, what and how, Chem. Soc. Rev., 42 (15), 6223-6235.

[6] Lima, L.C.D., Peres, D.G.C., and Mendes, A.A., 2018, Kinetic and thermodynamic studies on the enzymatic synthesis of wax ester catalyzed by lipase immobilized on glutaraldehyde-activated rice husk particles, Bioprocess. Biosyst. Eng., 41 (7), 991-1002.

[7] Bonazza, H.L., Manzo, R.M., dos Santos, J.C.S., and Mammarella, E.J., 2018, Operational and thermal stability analysis of Thermomyces lanuginosus lipase covalently immobilized onto modified chitosan supports, Appl. Biochem. Biotechnol., 184 (1), 182196.

[8] Cao, L.P., Wang, J.J., Zhou, T., Ruan, R., and Liu, Y.Y., 2018, Bamboo (Phyllostachys pubescens) as a natural support for neutral protease immobilization, Appl. Biochem. Biotechnol., 186 (1), 109-121.

[9] Onoja, E., Attan, N., Chandren, S., Razak, F.I.A., Keyon, A.S.A., Mahat, N.A., and Wahab, R.A., 2017, Insights into the physicochemical properties of the Malaysian oil palm leaves as an alternative source of industrial materials and bioenergy, Malays. J. Fundam. Appl. Sci., 13 (4), 623-631.

[10] Hartmann, M., and Kostrov, X., 2013, Immobilization of enzymes on porous silicas benefits and challenges, Chem. Soc. Rev., 42 (15), 6277-6289.

[11] Zhou, Z., and Hartmann, M., 2012, Recent progress in biocatalysis with enzymes immobilized on 
mesoporous hosts, Top. Catal., 55 (16-18), 1081-1100.

[12] Onoja, E., Chandren, S., Razak, F.I.A., Mahat, N.A., and Wahab, R.A., 2019, Oil palm (Elaeis guineensis) biomass in Malaysia: The present and future prospects, Waste Biomass Valorization, 10 (8), 2099-2117.

[13] Mateo, C., Palomo, J.M., Fernandez-Lorente, G., Guisan, J.M., and Fernandez-Lafuente, R., 2007, Improvement of enzyme activity, stability and selectivity via immobilization techniques, Enzyme Microb. Technol., 40 (6), 1451-1463.

[14] Rodrigues, R.C., Ortiz, C., Berenguer-Murcia, Á., Torres, R., and Fernández-Lafuente, R., 2013, Modifying enzyme activity and selectivity by immobilization, Chem. Soc. Rev., 42 (15), 6290-6307.

[15] Manoel, E.A., dos Santos. J.C.S., Freire, D.M.G., Rueda, N., and Fernandez-Lafuente, R., 2015, Immobilization of lipases on hydrophobic supports involves the open form of the enzyme, Enzyme Microb. Technol., 71, 53-57.

[16] Sassolas, A., Blum, L.J., and Leca-Bouvier, B.D., 2012, Immobilization strategies to develop enzymatic biosensors, Biotechnol. Adv., 30 (3), 489-511.

[17] Rahman, I.N.A., Attan, N., Mahat, N.A., Jamalis, J., Keyon, A.S.A., and Kurniawan, C., 2018, Statistical optimization and operational stability of Rhizomucor miehei lipase supported on magnetic chitosan/chitin nanoparticles for synthesis of pentyl valerate, Int. J. Biol. Macromol., 115, 680-695.

[18] Mohamad, N.R., Huyop, F., Aboul-Enein, H.Y., Mahat, N.A., and Wahab, R.A., 2015, Response surface methodological approach for optimizing production of geranyl propionate catalysed by carbon nanotubes nanobioconjugates, Biotechnol. Biotechnol. Equip., 29 (4), 732-739.

[19] Liu, Y., and Hua, X., 2014, Production of biodiesel using a nanoscaled immobilized lipase as the catalyst, Catal. Lett., 144 (2), 248-251.

[20] Laveille, P., Falcimaigne, A., Chamouleau, F., Renard, G., Drone, J., Fajula, F., Pulvin, S., Thomas, D., Bailly, C., and Galarneau, A., 2010, Hemoglobin immobilized on mesoporous silica as effective material for the removal of polycyclic aromatic hydrocarbons pollutants from water, New J. Chem., 34 (10), 2153-2165.

[21] Spinelli, D., Coppi, S., Basosi, R., and Pogni, R., 2014, Biosynthesis of ethyl butyrate with immobilized Candida rugosa lipase onto modified Eupergit ${ }^{\circ} \mathrm{C}$, Biocatalysis, 1 (1), 1-12.

[22] Barbosa, O., Ortiz, C., Berenguer-Murcia, A., Torres, R., Rodrigues, R.C., and Fernandez-Lafuente, R., 2014, Glutaraldehyde in bio-catalysts design: A useful crosslinker and a versatile tool in enzyme immobilization, RSC Adv., 4 (4), 1583-1600.

[23] Gunda, N.S.K., Singh, M., Norman, L., Kaur, K., and Mitra, S.K., 2014, Optimization and characterization of biomolecule immobilization on silicon substrates using (3-aminopropyl) triethoxysilane (APTES) and glutaraldehyde linker, Appl. Surf. Sci., 305, 522-530.

[24] Migneault, I., Dartiguenave, C., Bertrand, M.J., and Waldron, K.C., 2004, Glutaraldehyde: Behavior in aqueous solution, reaction with proteins, and application to enzyme crosslinking, Biotechniques, 37 (5), 790-802.

[25] Elias, N., Chandren, S., Razak, F.I.A., Jamalis, J., Widodo, N., and Wahab, R.A., 2018, Characterization, optimization and stability studies on Candida rugosa lipase supported on nanocellulose reinforced chitosan prepared from oil palm biomass, Int. J. Biol. Macromol., 114, 306-316.

[26] Johan, E., Ogami, K., Matsue, N., Itagaki, Y., and Aono, H., 2016, Fabrication of high purity silica from rice husk and its conversion into ZSM-5, ARPN J. Eng. Appl. Sci., 11 (6), 4006-4010.

[27] Dodson, J.R., Cooper, E.C., Hunt, A.J., Matharu, A., Cole, J., Minihan, A., Clark, J.H., and Macquarrie, D.J., 2013, Alkali silicates and structured mesoporous silicas from biomass power station wastes: The emergence of bio-MCMs, Green Chem., 15 (5), 1203-1210.

[28] Zhu, W., Zhang, Y., Hou, C., Pan, D., He, J., and Zhu, H., 2016, Covalent immobilization of lipases on monodisperse magnetic microspheres modified with PAMAM-dendrimer, J. Nanopart. Res., 18 (2), 32. 
[29] Bradford, M.M., 1976, A rapid and sensitive method for the quantitation of microgram quantities of protein utilizing the principle of protein-dye binding, Anal. Biochem., 72 (1-2), 248-254.

[30] Zhang, G., Zhao, P., and Xu, Y., 2017, Development of amine-functionalized hierarchically porous silica for $\mathrm{CO}_{2}$ capture, J. Ind. Eng. Chem., 54, 59-68.

[31] Wu, C., Zhou, G., Jiang, X., Ma, J., Zhang, H., and Song, H., 2012, Active biocatalysts based on Candida rugosa lipase immobilized in vesicular silica, Process Biochem., 47 (6), 953-959.

[32] Motevalizadeh, S.F., Khoobi, M., Shabanian, M., Asadgol, Z., Faramarzi, M.A., and Shafiee, A., 2013, Polyacrolein/mesoporous silica nanocomposite: Synthesis, thermal stability and covalent lipase immobilization, Mater. Chem. Phys., 143 (1), 76-84.

[33] Majoul, N., Aouida, S., and Bessaïs, B., 2015, Progress of porous silicon APTES-functionalization by FTIR investigations, Appl. Surf. Sci., 331, 388-391.

[34] Isah, A.A., Mahat, N.A., Jamalis, J., Attan, N., Zakaria, I.I., Huyop, F., and Wahab, R.A., 2017, Synthesis of geranyl propionate in a solvent-free medium using Rhizomucor miehei lipase covalently immobilized on chitosan-graphene oxide beads, Prep. Biochem. Biotechnol., 47 (2), 199-210.
[35] Wahab, R.A., Basri, M., Rahman, M.B., Rahman, R.N., Salleh, A.B., and Leow, T.C., 2012, Combination of oxyanion Gln114 mutation and medium engineering to influence the enantioselectivity of thermophilic lipase from Geobacillus zalihae, Int. J. Mol. Sci., 13 (9), 1166611680.

[36] Manan, F.M.A., Attan, N., Zakaria, Z., Keyon, A.S.A., and Wahab, R.A., 2018, Enzymatic esterification of eugenol and benzoic acid by a novel chitosan-chitin nanowhiskers supported Rhizomucor miehei lipase: Process optimization and kinetic assessments, Enzyme Microb. Technol., 108, 42-52.

[37] Stark, M.B., and Holmberg, K., 1989, Covalent immobilization of lipase in organic solvents, Biotechnol. Bioeng., 34 (7), 942-950.

[38] Öztürk, H., Pollet, E., Phalip, V., Güvenilir, Y., and Avérous, L., 2016, Nanoclays for lipase immobilization: Biocatalyst characterization and activity in polyester synthesis, Polymer, 8 (12), 416.

[39] Soares, I.P., Rezende, T.F., Pereira, R.C.C., dos Santos, C.G., and Fortes, I.C.P., 2011, Determination of biodiesel adulteration with raw vegetable oil from ATR-FTIR data using chemometric tools, J. Braz. Chem. Soc., 22 (7), 1229-1235. 